\section{OAK RIDGE NATIONAL LABORATORY}

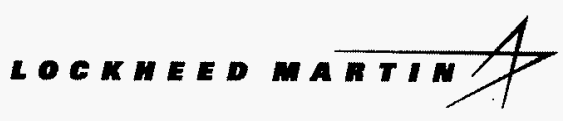

\section{INTERACTIONS OF ZIRCALOY CLADDING WITH GALLIUM 1997 STATUS}

RECEIVEO

DEC 121997

OSTI

D. F. Wilson

J. R. DiStefano

J. F. King

E. T. Manneschmidt

J. P. Strizak

\title{
MASTER YPU
}


This report has been reproduced directly from the best available copy.

Available to DOE and DOE contractors from the Office of Scientific and Technical Information, P.O. Box 62, Oak Ridge, TN 37831; prices available from (423)576-8401.

Available to the public from the National Technical Information Service, U.S. Department of Commerce, 5285 Port Royal Rd., Springfield, VA 22161.

This report was prepared as an account of work sponsored by an agency of the United States Government. Neither the United States Government nor any agency thereof, nor any of their employees, makes any warranty, express or implied, or assumes any legal liability or responsibility for the accuracy, completeness, or usefulness of any information, apparatus, product, or process disclosed, or represents that its use would not infringe privately owned rights. Reference herein to any specific commercial product, process, or service by trade name, trademark, manufacturer, or otherwise, does not necessarily constitute or imply its endorsement, recommendation, or favoring by the United States Government or any agency thereof. The views and opinions of authors expressed herein do not necessarily state or reflect those of the United States Government or any agency thereof. 
ORNL/TM-13505

Metals and Ceramics Division

\title{
INTERACTIONS OF ZIRCALOY CLADDING WITH GALLIUM 1997 STATUS
}

\author{
D. F. Wilson \\ J. R. DiStefano \\ J. F. King \\ E. T. Manneschmidt \\ J. P. Strizak
}

Date Published: November 1997

NOTICE: This document contains information of a preliminary nature.

It is subject to revision or correction and therefore does not represent a final report.

Prepared for the

U.S, Department of Energy

Office of Fissile Materials Disposition

GA 0102014

\author{
Prepared by the \\ OAK RIDGE NATIONAL LABORATORY \\ Oak Ridge, Tennessee 37831-6285 \\ managed by \\ LOCKHEED MARTIN ENERGY RESEARCH \\ for the \\ U.S. DEPARTMENT OF ENERGY \\ under contract DE-AC05-96OR22464
}




\section{CONTENTS}

TABLES $\ldots \ldots \ldots \ldots \ldots \ldots \ldots \ldots \ldots \ldots \ldots \ldots \ldots \ldots \ldots \ldots \ldots \ldots \ldots \ldots \ldots \ldots \ldots$

FIGURES $\ldots \ldots \ldots \ldots \ldots \ldots \ldots \ldots \ldots \ldots \ldots \ldots \ldots \ldots \ldots \ldots \ldots \ldots \ldots \ldots \ldots \ldots \ldots$

ACRONYMS $\ldots \ldots \ldots \ldots \ldots \ldots \ldots \ldots \ldots \ldots \ldots \ldots \ldots \ldots \ldots \ldots \ldots \ldots \ldots \ldots \ldots \ldots \ldots \ldots \ldots$

ABSTRACT $\ldots \ldots \ldots \ldots \ldots \ldots \ldots \ldots \ldots \ldots \ldots \ldots \ldots \ldots \ldots \ldots \ldots \ldots \ldots \ldots \ldots \ldots$

1. INTRODUCTION $\ldots \ldots \ldots \ldots \ldots \ldots \ldots \ldots \ldots \ldots \ldots \ldots \ldots \ldots \ldots \ldots \ldots \ldots \ldots \ldots \ldots$

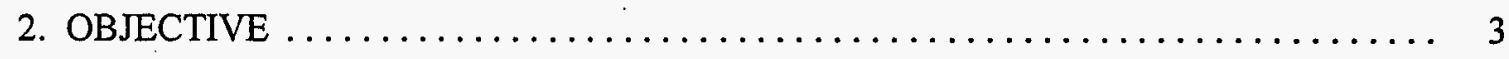

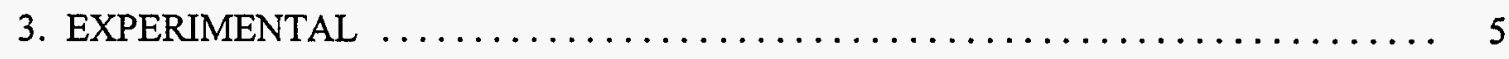

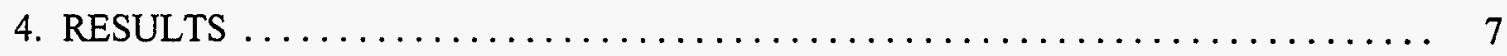

4.1 PHASE I CORROSION BY LIQUID GALLIUM $\ldots \ldots \ldots \ldots \ldots \ldots \ldots \ldots . \ldots \ldots$

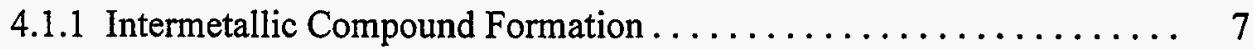

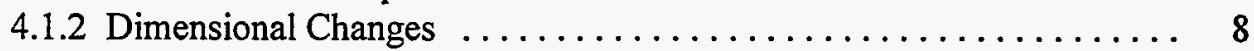

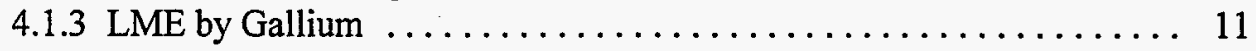

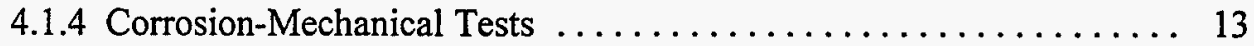

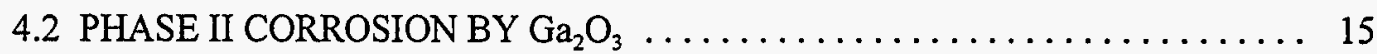

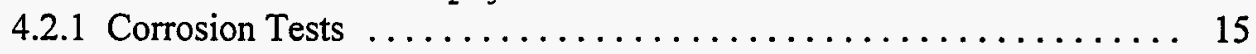

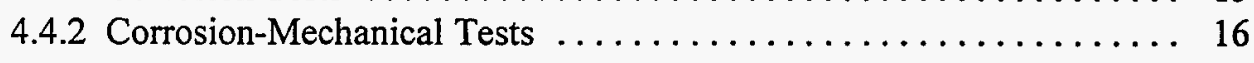

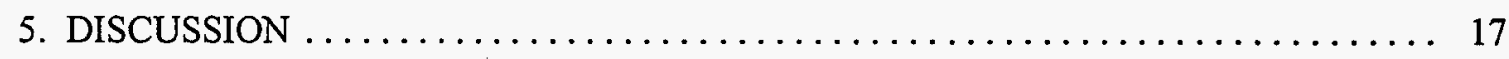

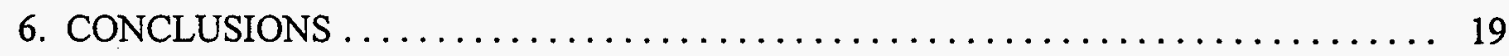

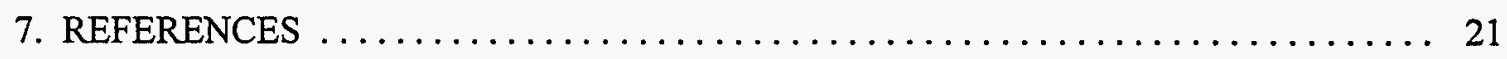

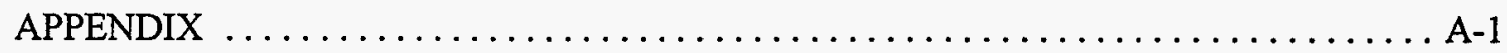




\section{TABLES}

Table I. Composition range of standard Zircaloys (weight percent except where noted) $\ldots . .5$

A.1 Additional compatibility tests of zirconium/Zircaloy with gallium or $\mathrm{Ga}_{2} \mathrm{O}_{3} \ldots \ldots \ldots$ A-1

A.2 Status of corrosion tests of Zircaloy with gallium metal $\ldots \ldots \ldots \ldots \ldots \ldots \ldots \ldots$

A.3 Status of corrosion tests of Zircaloy with $\mathrm{Ga}_{2} \mathrm{O}_{3} \ldots \ldots \ldots \ldots \ldots \ldots \ldots \ldots \ldots \ldots \ldots \ldots \ldots \ldots$

A.4 Status of mechanical tests of Zircaloy with gallium metal $\ldots \ldots \ldots \ldots \ldots \ldots \ldots$ A-3

A.5 Status of corrosion-mechanical tests of Zircaloy with $\mathrm{Ga}_{2} \mathrm{O}_{3} \ldots \ldots \ldots \ldots \ldots \ldots \ldots$ 


\section{FIGURES}

Fig. 1. Intermetallic compounds formed between gallium and zirconium

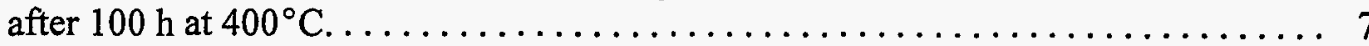

Fig. 2. Brittle intermetallic compounds formed between gallium and zirconium at $400^{\circ} \mathrm{C}$.

Fig. 3. Cross section showing $\mathrm{Zr} / \mathrm{ICF}$ interface after reaction of $\mathrm{Zr}$ with $\mathrm{Ga}$ at $400^{\circ} \mathrm{C} \ldots \ldots 8$

Fig. 4. Cross sections of Zircaloy tubes after corrosion testing with excess gallium at $500^{\circ} \mathrm{C}$ showing dimensional distortion. $\ldots \ldots \ldots \ldots \ldots \ldots \ldots \ldots \ldots \ldots \ldots \ldots$

Fig. 5. Corrosion testing with various amounts gallium at $500^{\circ} \mathrm{C} . \ldots \ldots \ldots \ldots \ldots \ldots$

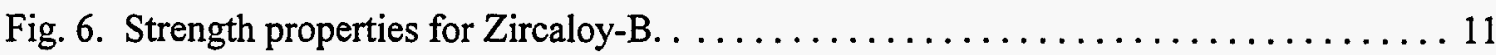

Fig. 7. Ductility properties for Zircaloy-B.. $\ldots \ldots \ldots \ldots \ldots \ldots \ldots \ldots \ldots \ldots \ldots \ldots \ldots$

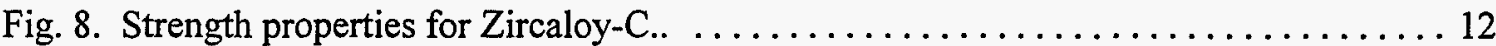

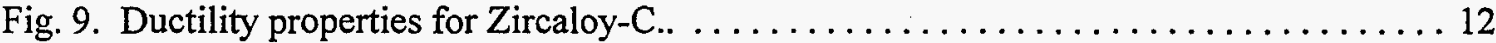

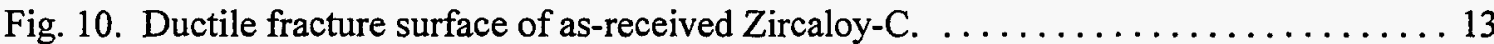

Fig. 11. Nonductile features of fracture surface of Zircaloy-C after $200 \mathrm{~h}$ at $300^{\circ} \mathrm{C} \ldots \ldots \ldots 14$

Fig. 12. Results of corrosion tests of Zircaloy with $\mathrm{Ga}_{2} \mathrm{O}_{3}$ at 300,500 , and $700^{\circ} \mathrm{C}, \ldots \ldots 15$

Fig. 13. Little evidence of interaction between Zircaloy and $1778 \mathrm{ppm}$

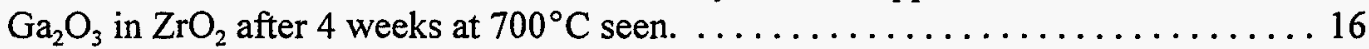

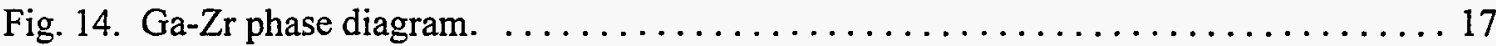




\section{ACRONYMS}

$\begin{array}{ll}\text { EBW } & \text { electron beam welding } \\ \text { ICF } & \text { intermetallic compound formation } \\ \text { LANL } & \text { Los Alamos National Laboratory } \\ \text { LBW } & \text { laser beam welding } \\ \text { LME } & \text { liquid metal embrittlement } \\ \text { LWR } & \text { light-water reactor } \\ \text { MOX } & \text { mixed oxide } \\ \text { ORNL } & \text { Oak Ridge National Laboratory } \\ \text { PCI } & \text { pellet clad interaction } \\ \text { WG } & \text { weapons grade }\end{array}$




\section{ABSTRACT}

A four-phase program has been implemented to evaluate the effect of gallium in mixed oxide (MOX) fuel derived from weapons grade (WG)-plutonium on Zircaloy cladding performance. The objective is to demonstrate that low levels of gallium will not compromise the performance of the MOX fuel system in LWR. This graded, four-phase experimental program will evaluate the performance of prototypic Zircaloy cladding materials against (1) liquid gallium (Phase I), (2) various concentrations of $\mathrm{Ga}_{2} \mathrm{O}_{3}$ (Phase II), (3) centrally heated surrogate fuel pellets with expected levels of gallium (Phase III), and (4) centrally heated prototypic MOX fuel pellets (Phase IV). This status report describes the results of an initial series of tests for phases I and II.

Three types of tests are being performed: (1) corrosion, (2) liquid metal embrittlement (LME), and (3) corrosion-mechanical. These tests are designed to determine the corrosion mechanisms, thresholds for temperature and concentration of gallium that may delineate behavioral regimes, and changes in mechanical properties of Zircaloy.

Initial results have generally been favorable for the use of WG-MOX fuel. The MOX fuel cladding, Zircaloy, does react with gallium to form intermetallic compounds at $2300^{\circ} \mathrm{C}$; however, this reaction is limited by the mass of gallium and is therefore not expected to be significant with a low level (in parts per million) of gallium in the MOX fuel. While continued migration of gallium into the initially formed intermetallic compound results in large stresses that can lead to distortion, this is also highly unlikely because of the low mass of gallium or gallium oxide present and expected clad temperatures below $400^{\circ} \mathrm{C}$. Furthermore, no evidence for grain boundary penetration by gallium has been observed. 


\section{INTRODUCTION}

The U.S. Department of Energy has established a dual-track approach to the disposition of plutonium arising from the dismantling of nuclear weapons. The dual-track approach involves both immobilization and reactor-based MOX fuel technologies. The MOX fuel option requires assessment of the potential impact of gallium (on the order of $10 \mathrm{ppm}$ ), not present in conventional MOX fuel, on cladding material performance. A previous report ${ }^{1}$ identified several $^{2}$ compatibility issues relating to the presence of gallium in MOX fuel and its possible reaction with fuel cladding.

Gallium initially present in the WG plutonium is removed, for the most part, during processing to produce MOX fuel. After blending the plutonium with uranium, about $10 \mathrm{ppm}$ gallium is expected in the sintered MOX fuel. Gallium is expected to be present as gallium oxide $\left(\mathrm{Ga}_{2} \mathrm{O}_{3}\right)$ and could be evolved as the suboxide $\left(\mathrm{Ga}_{2} \mathrm{O}\right)$. Migration of the evolved $\mathrm{Ga}_{2} \mathrm{O}$ and diffusion of gallium in the MOX matrix along thermal gradients could lead to locally high concentrations of gallium oxide. Thus, while the low concentration of gallium in MOX fuel greatly reduces the probability of significant interaction of gallium with Zircaloy fuel cladding, it does not assure that corrosion effects will necessarily be negligible.

A number of reaction routes are possible in this clad-WG-MOX fuel system, including:

$$
\left.\begin{array}{c}
\mathrm{Ga} \\
\mathrm{O} \cdot \mathrm{PuO}_{2} \\
\text { or } \\
\mathrm{Ga}{ }_{2} \mathrm{O} \\
\text { or } \\
\mathrm{Ga} \mathrm{O}_{3}
\end{array}\right\}+ \text { Zircaloy }-\mathrm{Ga}-\left\{\begin{array}{c}
\text { Surface alloy } \\
\text { or } \\
\text { Grain boundary penetration } \\
\text { or } \\
\text { Liquid metal embrittlement }
\end{array}\right.
$$

$$
G a_{2} \mathrm{O}_{3}+\mathrm{ZrO}_{2} \rightarrow\left\{\begin{array}{c}
\text { No reaction } \\
\text { or } \\
\text { Mixed oxide + crack }
\end{array}-\mathrm{Ga} \rightarrow\left\{\begin{array}{c}
\text { Surface alloy } \\
\text { or } \\
\text { Grain boundary penetration } \\
\text { or } \\
\text { Liquid metal embrittlement }
\end{array}\right.\right.
$$


Surface alloying or the formation of intermetallic compounds between Zircaloy and gallium should be mass limited and, therefore, superficial because of the expected low ratio of gallium to the surface area or volume of the Zircaloy cladding. While the expected concentration of gallium is low and there is very limited solubility of gallium in zirconium, especially at temperatures below $700^{\circ} \mathrm{C},{ }^{2}$ grain boundary penetration and LME remain as possible forms of localized corrosion.

Pellet clad interaction (PCI) leading to failure of the Zircaloy cladding in light-water reactors (LWRs) has been attributed to stresses in the cladding and one or more aggressive fission products. Stress corrosion cracking by iodine ${ }^{3,4}$ and LME by cadmium ${ }^{5,6}$ have been reported. It is also known that Zircaloy can be embrittled by low melting metals (LME), (e.g., mercury). ${ }^{7}$ LME is a form of environmentally induced embrittlement that can induce cracking or loss of ductility. LME requires wetting and a tensile stress but it does not require corrosion penetration. Experimentally, it has been demonstrated that gallium can cause embrittlement of some alloys (e.g., aluminum) at low temperatures. ${ }^{8} 9$ Experiments relative to LME of zirconium by gallium have been limited and inconclusive $;^{10}$ nevertheless, the possibility of a synergism between cadmium and gallium enhancing the probability of LME of Zircaloy cannot be ignored.

This report describes an initial series of gallium-cladding compatibility tests aimed at establishing confidence that low levels of residual gallium in WG MOX fuel do not affect its long-term compatibility with Zircaloy. In addition, it is important to understand the potential cladding interactions and the available safety margins with respect to gallium concentration. 


\section{OBJECTIVE}

The overall objective of this task is to demonstrate, to the extent possible, that small concentrations of gallium in MOX fuel will not compromise the performance of the fuel system in an LWR. While possible mechanisms for gallium interaction with Zircaloy have been identified, no significant data exist that demonstrate whether such reactions actually occur under LWR conditions and whether these reactions have any significant effects on cladding performance. PCI is a recognized phenomenon that can lead to embrittlement of Zircaloy by low-melting fission products in LWRs. Even so, current pressurized-water reactors and boilingwater reactors successfully operate due to mitigation techniques such as pellet design and operational control of transients that limit stresses in the clad. In the present program, a graded experimental approach to determining whether gallium is a problem is being pursued. The experimental approach is divided into four phases. In phase $\mathrm{I}$, three prototypic Zircaloy cladding materials are being exposed to liquid gallium. Three types of tests are being used: (1) corrosion, (2) LME, and (3) corrosion-mechanical. LME tests consist of constant extension rate tensile tests in gallium metal at low temperature $\left(30\right.$ and $\left.100^{\circ} \mathrm{C}\right)$ while corrosion-mechanical tests consist of first exposing the Zircaloy to gallium metal or $\mathrm{Ga}_{2} \mathrm{O}_{3}$ at a "high" temperature and then conducting a room temperature tensile test to evaluate corrosion product effects. While these phase I tests conditions (a thick film of gallium on all surfaces) are unlikely, they represent maximum gallium concentration boundary conditions. The test matrixes for these phase I tests are shown in the appendix.

In phase II, two types of tests are being conducted with the three cladding materials in contact with $\mathrm{Ga}_{2} \mathrm{O}_{3}$ : corrosion and corrosion-mechanical. In each type of test, four concentrations of $\mathrm{Ga}_{2} \mathrm{O}_{3}$ are being evaluated: $100 \%, 1 \%, 0.2 \%$, and $0.1 \%$. Although these levels of $\mathrm{Ga}_{2} \mathrm{O}_{3}$ are all considerably above what is expected, they allow the potential types of reactions to be more easily determined, and they will represent a nonconservative evaluation of $\mathrm{Ga}_{2} \mathrm{O}_{3}$ effects in this screening test phase. The test matrixes for phase II tests are shown in the appendix.

Phase III tests will expose cladding material to centrally heated surrogate fuel pellets to be manufactured by Los Alamos National Laboratory (LANL). These sintered annular pellets, $\mathrm{U} / \mathrm{Ce} / \mathrm{Ga} / \mathrm{O}$, should contain less than $1 \%$ gallium and have a density greater than $94 \%$. The Texas A\&M University Nuclear Science Center has designed a nonpressurized test system for 
these centrally-heated-pellet tests and will perform these tests. To simulate the thermal gradients across operating reactor pellets and test for thermally driven gallium diffusion, a small diameter ( 0.18-inch outside diameter) electric heater will be inserted into the center of the surrogate pellets. The heater will operate at a temperature of about $1000^{\circ} \mathrm{C}$ with a linear power of $15.7 \mathrm{~kW} / \mathrm{m}$. The experiment will be configured to produce a nominal cladding-pellet interface temperature of $400^{\circ} \mathrm{C}$. Six 4-in. "rodlets" will be centrally heated and periodically one will be withdrawn for evaluation (the longest time at temperature will be $5,000 \mathrm{~h}$ ).

Phase IV tests will be similar to phase III tests, but prototypic MOX fuel pellets will be used. These tests will be performed at the Oak Ridge National Laboratory (ORNL) with MOX pellets produced by LANL. 


\section{EXPERIMENTAL}

Experiments are being performed using typical Zircaloy claddings, Zircaloy-2, Zircaloy4, and Zirlo, whose compositional ranges are presented in Table I.

Table I. Composition of alloys based on zirconium (weight percent except where noted)

\begin{tabular}{lcccccc}
\hline Name & $\mathrm{Sn}$ & $\mathrm{Fe}$ & $\mathrm{Cr}$ & $\mathrm{Ni}$ & $\mathrm{Nb}$ & $\begin{array}{c}\mathrm{O} \\
(\mathrm{ppm})\end{array}$ \\
\hline Zircaloy-2* $^{*}$ & $1.2-1.7$ & $0.07-0.2$ & $\begin{array}{c}0.05- \\
0.15\end{array}$ & $\begin{array}{c}0.03- \\
0.08\end{array}$ & & $1000-1400$ \\
& & & & & $1000-1400$ \\
Zircaloy-4* $^{*}$ & $1.2-1.7$ & $0.18-0.24$ & $\begin{array}{c}0.07- \\
0.13\end{array}$ & & & \\
& & & $0.02-$ & $900-1200$ \\
Zirlo $^{\dagger}$ & $0.96-$ & $0.094-$ & $\begin{array}{c}79-83 \\
\text { ppm }\end{array}$ & & 1.14 & \\
\hline
\end{tabular}

"R. W. Cahn, P. Haasen, E. J. Kramer, "Materials, Science, and Technology", Vol. 10b, p. 11, Nuclear Materials, Part 2, 1994.

${ }^{\dagger}$ G. P. Sabol, R. J. Comstock, R. A. Weiner, P. Larouere, and R. N. Stanutz, "In-Reactor Corrosion Performance of Zirlo and Zircaloy-4," Zirconium in the Nuclear Industry: Tenth International Symposium, pp. 724-744, in ASTM STP 1245, A. M. Garde and E. R. Bradley, Eds., American Society for Testing and Materials, Philadelphia, 1994.

The Zircaloy tubing was machined into two different lengths, one for corrosion tests and the other for LME or corrosion-mechanical tests. End caps with and without threaded ends were machined from Zircaloy bar stock for tensile and corrosion tests, respectively. First, one end cap was welded to the specimen tube, the required quantity of reactant was then added, and the other end cap welded in place. Because of the reactive nature of the zirconium alloys with oxygen and nitrogen, all welding was performed in either high vacuum using the electron beam welding (EBW) process or in a high-purity, helium-purged welding chamber using the laser beam welding (LBW) process. The completed test specimens for corrosion tests were encapsulated in an evacuated quartz capsule. For mechanical testing above $100^{\circ} \mathrm{C}$, a chamber to provide a protective atmosphere around the test specimens was designed and fabricated. This protective chamber precludes the reaction of zirconium alloys with the ambient oxygen and nitrogen during testing. 
In addition to some preliminary tests performed at 400 and $600^{\circ} \mathrm{C}$, tube specimens containing gallium metal were corrosion tested at three temperatures $\left(30,100\right.$, and $\left.500^{\circ} \mathrm{C}\right)$ for two exposure times (200 and/or $700 \mathrm{~h}$ ); those containing gallium oxide or surrogate galliumcontaining oxide were also tested at three temperatures $\left(300,500\right.$, and $\left.700^{\circ} \mathrm{C}\right)$ for two exposure times ( 6 weeks and 12 weeks). Preliminary tests with gallium and $\mathrm{Ga}_{2} \mathrm{O}_{3}$ were also conducted on zirconium and non-vendor-supplied Zircaloy tubing as noted.

Post-test analyses of cross sections of the clad tubes included metallography, fractography, and chemical microprobe. In the case of the corrosion tests, evidence of wall thinning, grain boundary penetration, transgranular attack, and intermetallic compound formation (ICF), when present, were documented. For the mechanical tests (LME or corrosionmechanical), the tensile strength and ductility of specimens tested in the presence of gallium were compared to those tested in the absence of gallium. 


\section{RESULTS}

Tables summarizing the status of work performed are presented in the appendix. Nonvendor-supplied materials are listed with their trade names. Vendor-supplied materials are listed generically.

\subsection{PHASE I CORROSION BY LIQUID GALLIUM}

\subsubsection{Intermetallic Compound Formation}

In preliminary corrosion tests of zirconium by liquid gallium at $400^{\circ} \mathrm{C}$ and Zircaloy-2 (non-vendor-supplied) at $600^{\circ} \mathrm{C}$, ICF was found as would be predicted from the galliumzirconium phase diagram. As shown in Fig. 1, electron beam microprobe analysis identified several intermetallic compounds. No unreacted gallium remained in these tests. These intermetallic compounds are hard and brittle as shown in Fig. 2.

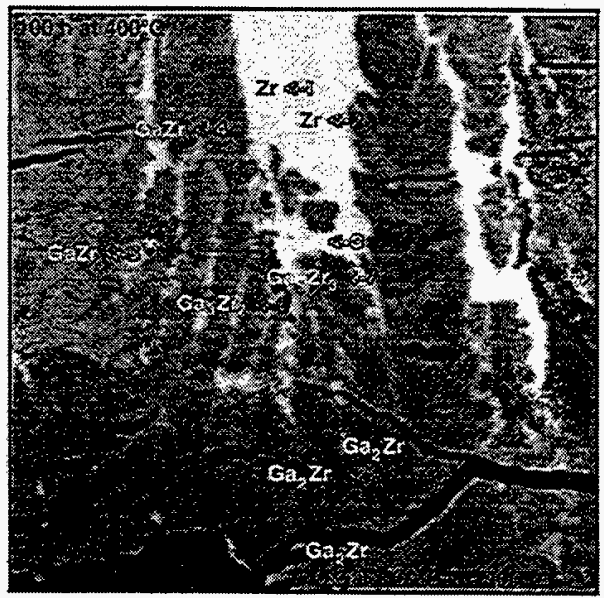

Fig. 1. Intermetallic compounds formed between gallium and zirconium after $100 \mathrm{~h}$ at $400^{\circ} \mathrm{C}$.

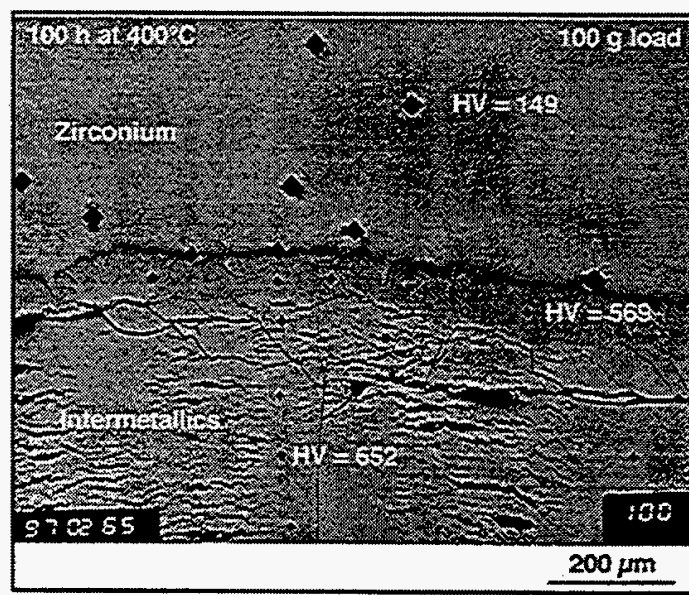

Fig. 2. Brittle intermetallic compounds formed between gallium and zirconium at $400^{\circ} \mathrm{C}$.

There was no evidence of selective grain boundary penetration, as shown in Fig. 3, and no evidence of selective dissolution of tin or other constituents of Zircaloy. 


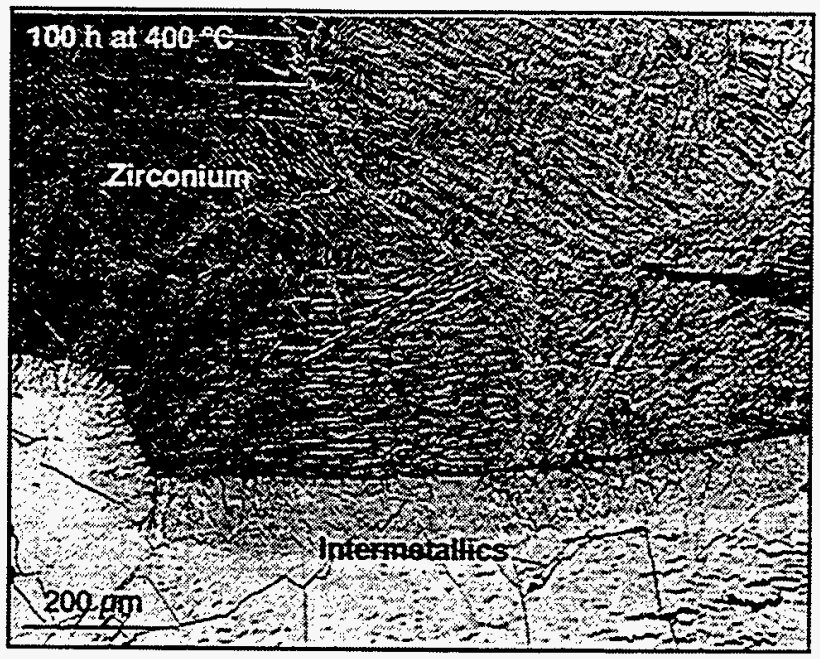

Fig. 3. Cross section showing $\mathrm{Zr} / \mathrm{ICF}$ interface after reaction of $\mathrm{Zr}$ with $\mathrm{Ga}$ at $400^{\circ} \mathrm{C}$. No evidence of grain boundary penetration was seen.

In a subsequent series of tests of vendor-supplied tubing, Zircaloy-B and Zircaloy-C were exposed to gallium at 30,100 , and $500^{\circ} \mathrm{C}$ for times of $200 \mathrm{and} / \mathrm{or} 700 \mathrm{~h}$, as shown in the appendix. At 30 and $100^{\circ} \mathrm{C}$ there was no evidence of corrosion after $700 \mathrm{~h}$, and unreacted liquid gallium was recovered upon completion of the tests. At $500^{\circ} \mathrm{C}$, all the gallium reacted, resulting in ICF as had been previously observed in the preliminary tests. There was no difference between 200 and $700 \mathrm{~h}$. Once again, there was no evidence of selective grain boundary attack.

\subsubsection{Dimensional Changes}

One unanticipated result of the corrosion tests was a dimensional change that occurred with thin-walled, vendor-supplied material accompanying ICF at $500^{\circ} \mathrm{C}$ as shown in Fig. 4. This dimensional change had not been observed in the preliminary tests of non-vendor-supplied material in which the wall thickness of the test capsule was larger; in which the end-cap design was such that there was no crevice where the cap was joined to the capsule; and where EBW was used to close the capsule instead of LBW. With EBW, the atmosphere inside the closed capsule was vacuum and the only internal pressure was the negligible vapor pressure of gallium. In contrast, with LBW the atmosphere was helium (slightly $<1 \mathrm{~atm}$ ) and the internal pressure increases with temperature. In subsequent tests, however, neither EBW (Fig. 4b) nor an end-cap closure with no crevice (Fig. 4c) prevented dimensional changes resulting from ICF. 


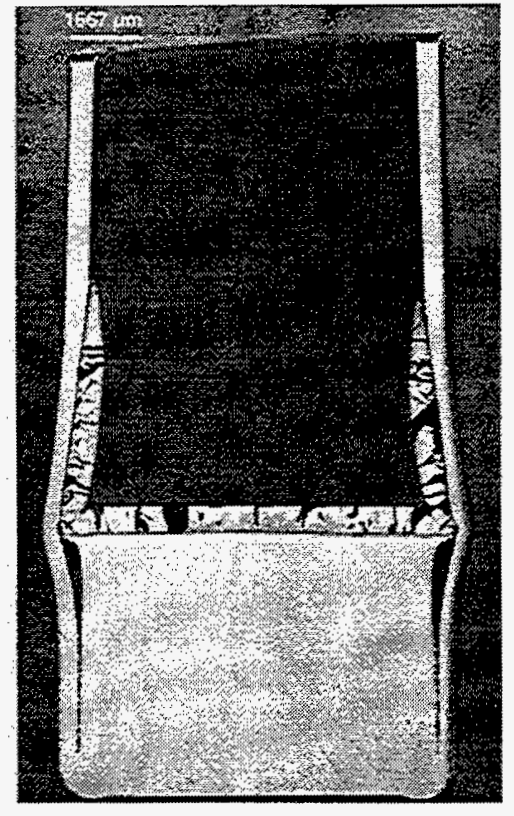

a

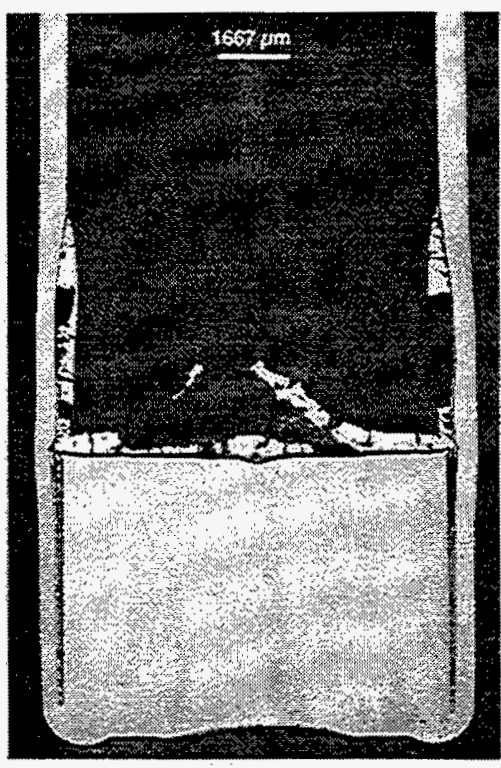

b

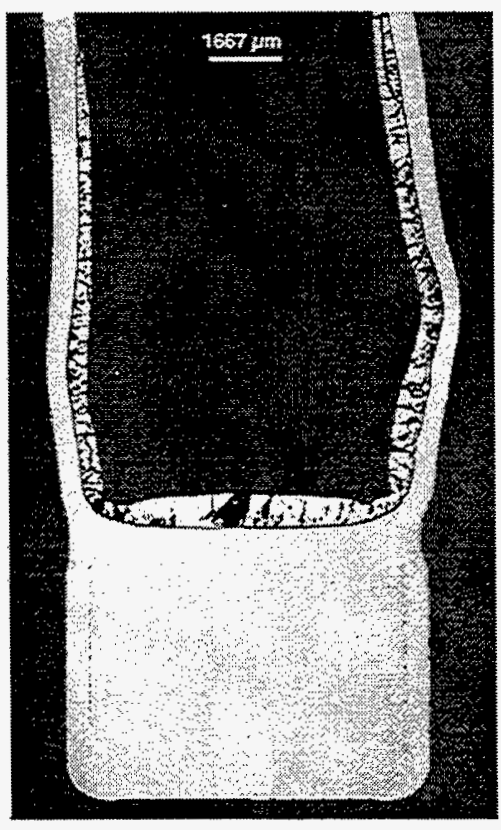

c

Fig. 4. Cross sections of Zircaloy tubes after corrosion testing with excess gallium (Ga) at $500^{\circ} \mathrm{C}$ showing dimensional distortion. $\mathrm{a}=0.5 \mathrm{~g} \mathrm{Ga}, \mathrm{b}=\mathrm{EBW}, 0.5 \mathrm{~g} \mathrm{Ga}, \mathrm{c}=$ no crevice, $0.6 \mathrm{~g} \mathrm{Ga}$. 
To evaluate the effects of $100 \mathrm{ppm}$ cadmium in gallium, the amount of gallium was $\sim 4$ times that used in previous tests. This was necessary so that the amount of cadmium to be added $(0.0001 \mathrm{~g})$ would not exceed $100 \mathrm{ppm}$, and the $0.0001 \mathrm{~g}$ of cadmium was the minimum that could be weighed and handled. This larger amount of gallium further increased the amount of gallium available after formation of the initial intermetallic compound and resulted in greater dimensional distortion.

Subsequently, the effect of lower ratios of weight of gallium to surface area of Zircaloy on dimensional distortion was investigated. When the weight of gallium was reduced by factors of 2.5, 5, and 10, (Fig. 5), distortion decreased and did not occur at all for the factor of 10 reduction. In a typical LWR fuel rod, the weight of gallium to surface area of Zircaloy should be $\leq 10^{-5}$ while the lowest ratio tested in this study was $\sim 10^{-1}$. Hence, it is highly unlikely that dimensional distortion due to gallium will occur in a fuel rod.

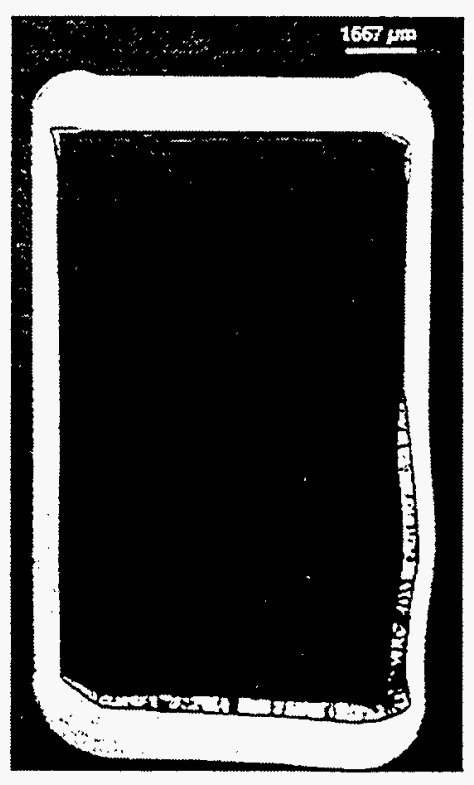

a

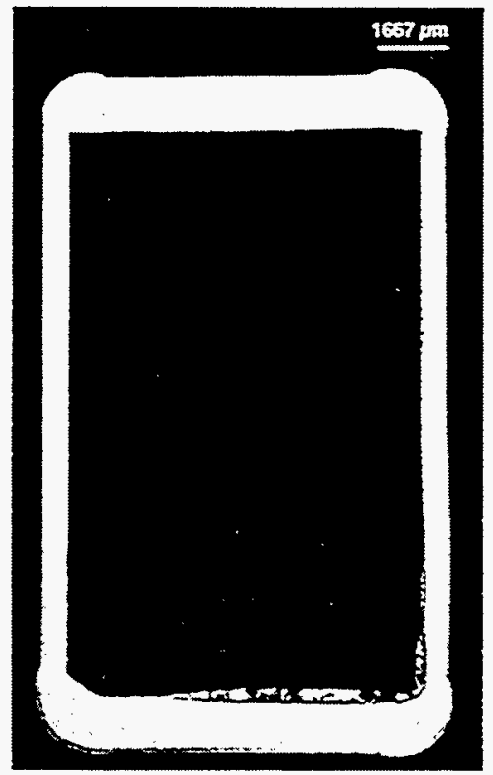

b

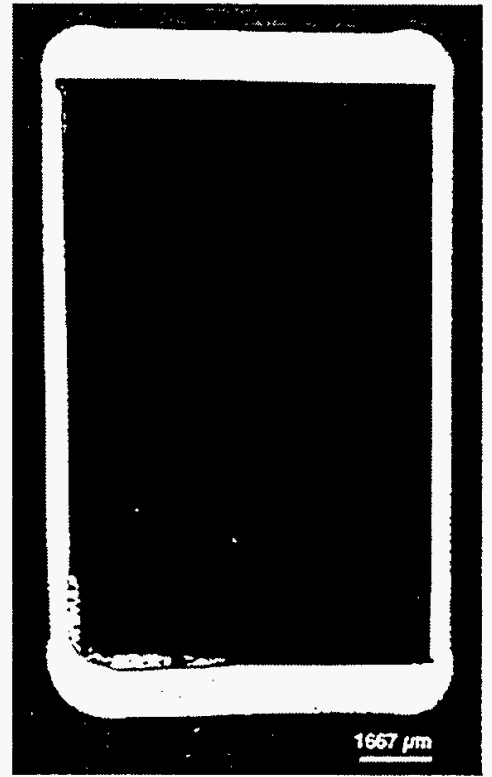

c

Fig. 5. Corrosion testing with gallium (Ga) at $500^{\circ} \mathrm{C}$. a $=0.2 \mathrm{~g} \mathrm{Ga}$, shows less dimensional distortion; $\mathrm{b}=0.09 \mathrm{~g} \mathrm{Ga}$, shows minor dimensional distortion; $\mathrm{c}=0.05 \mathrm{~g} \mathrm{Ga}$, shows no dimensional distortion. 


\subsubsection{LME by Gallium}

LME tests are designed to evaluate the effect of liquid gallium at low temperature on the mechanical properties of Zircaloy. Because of difficulties in designing a test specimen, data are just becoming available. Tensile properties for the specimens tested to date are summarized in Figs. 6 to 9. Valid data for ductility of specimens with gallium were not obtained because

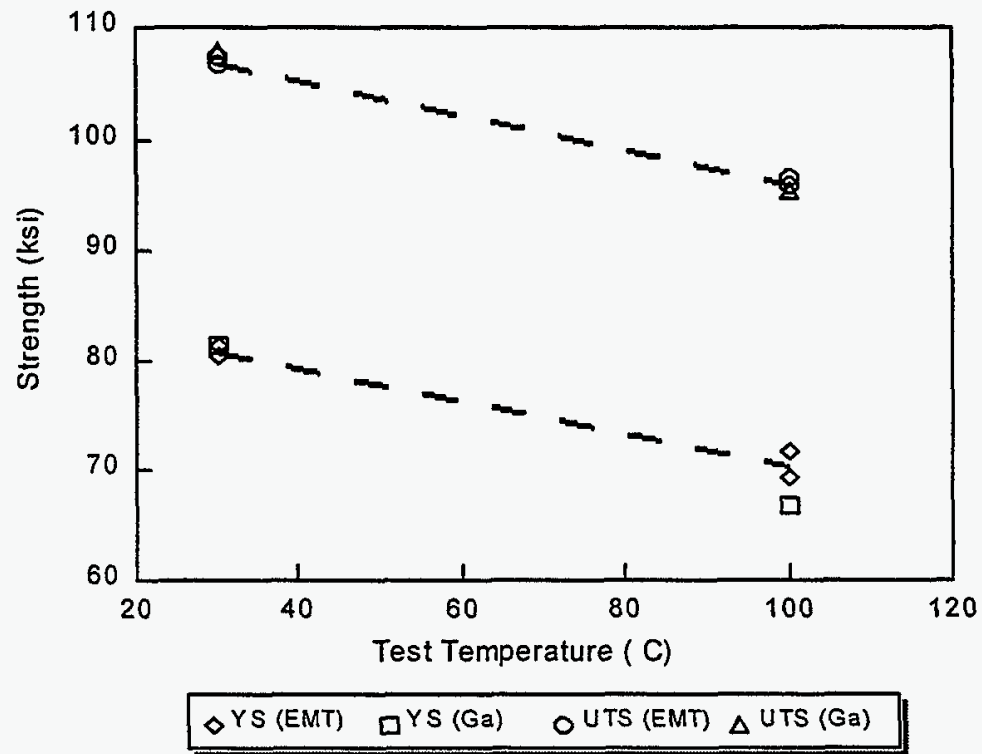

Fig. 6. Strength properties for Zircaloy-B. $(E M T=$ no gallium).

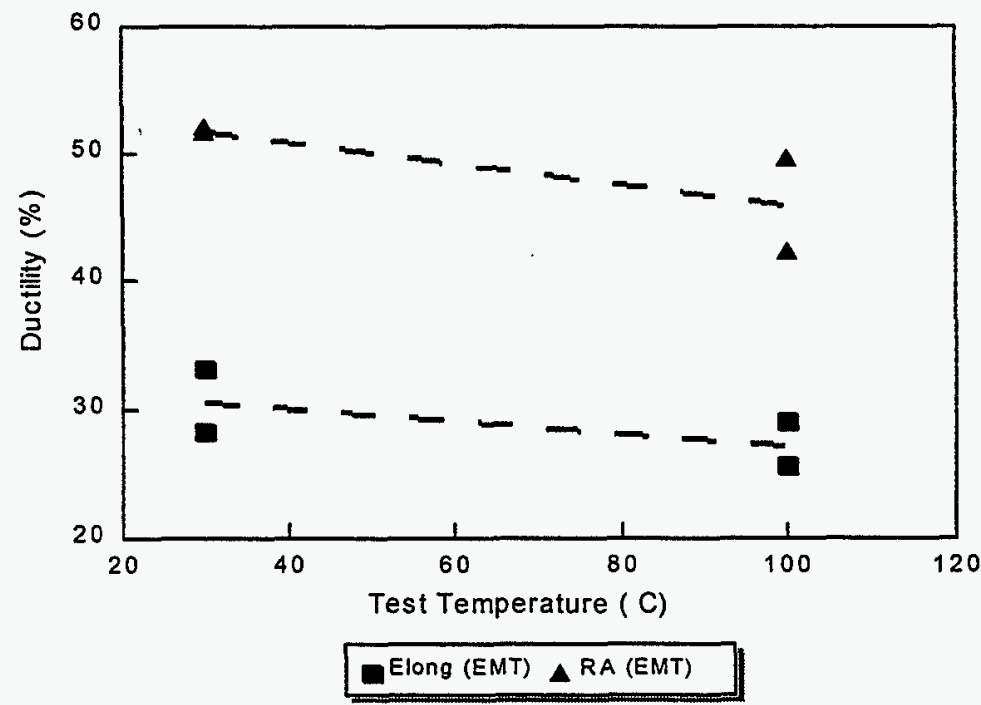

Fig. 7. Ductility properties for Zircaloy-B. $(E M T=$ no gallium). 


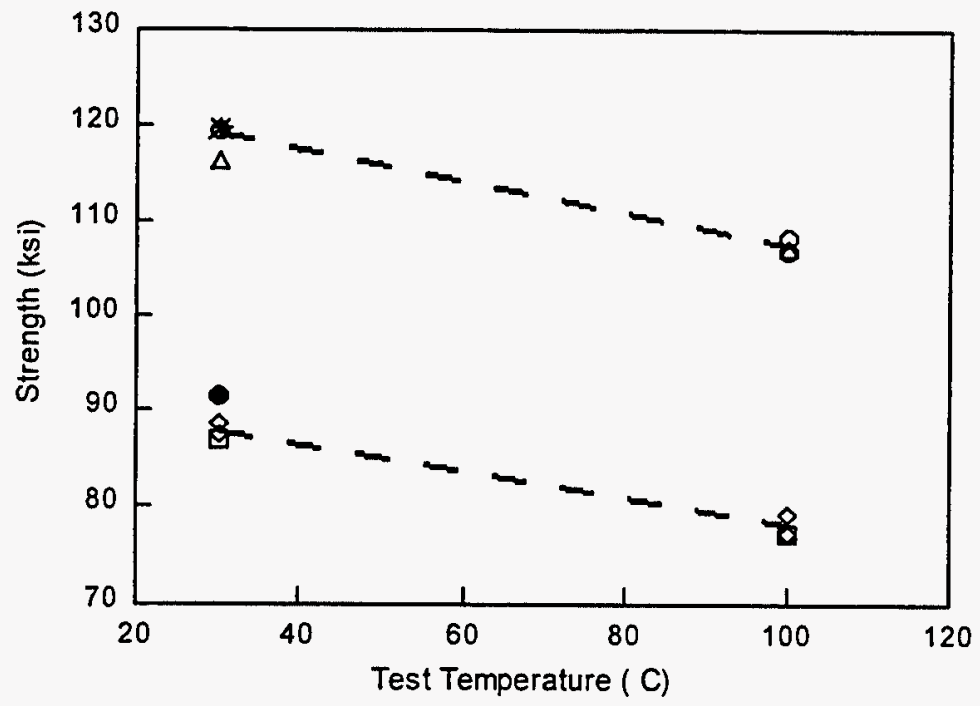

\begin{tabular}{|lll|}
\hline OYS (EMT) & $\square^{Y S(G a)}$ & OUTS (EMT) \\
$\Delta$ UTS (Ga) & YS (Ga@300) & *UTS (Ga@300) \\
\hline
\end{tabular}

Fig. 8. Strength properties for Zircaloy-C. $(E M T=$ no gallium).

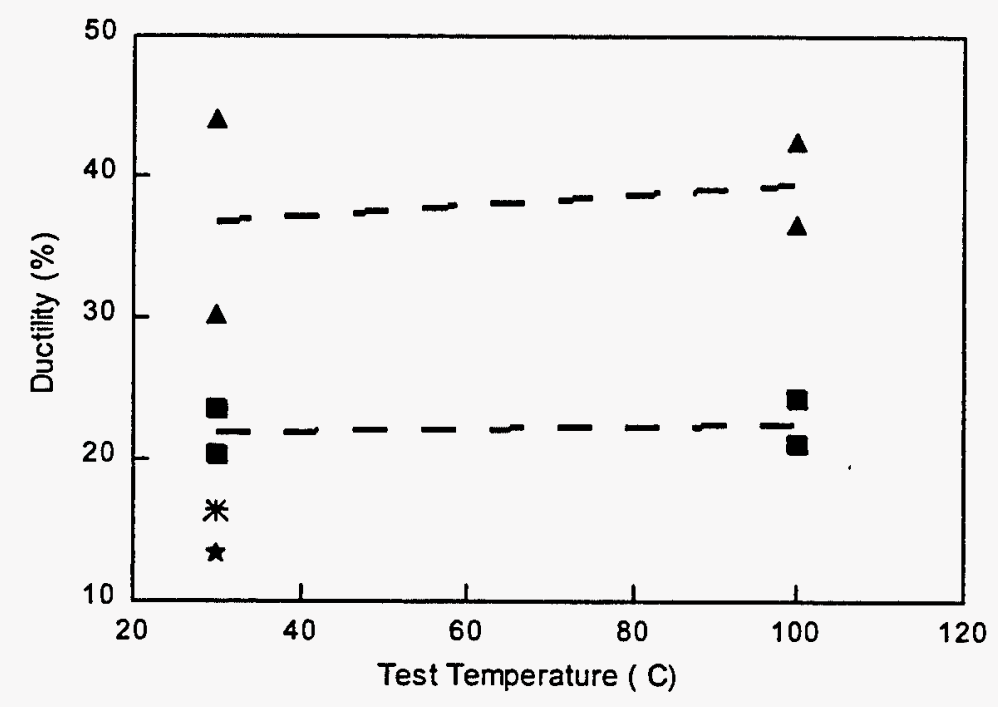

\begin{tabular}{ll}
\hline Elong (EMT) & $\triangle$ RA (EMT) \\
$\star$ Elong (Ga@300) & * RA (Ga@300)
\end{tabular}

Fig. 9. Ductility properties for Zircaloy-C. $(E M T=$ no gallium, and $\mathrm{Ga} @ 300=$ pre-exposed to gallium at $300^{\circ} \mathrm{C}$ for $200 \mathrm{~h})$. 
during tensile testing the specimens collapsed down onto tungsten rods that were used inside the tube specimens to reduce the required quantity of gallium . Based on the limited data obtained thus far, there is little, if any, change in the strength properties of Zircaloy materials at 30 and $100^{\circ} \mathrm{C}$ as a result of testing in liquid gallium. However, there was about a $10 \%$ decrease in yield and ultimate tensile strengths for all the materials between 30 and $100^{\circ} \mathrm{C}$. In as-received material, ductility did not change appreciably between 30 and $100^{\circ} \mathrm{C}$. The fracture surface of asreceived Zircaloy-C, as shown in Fig. 10, exhibits typical ductile features. Fractures of galliumcontaining capsules were not examined because of the design problem discussed above.

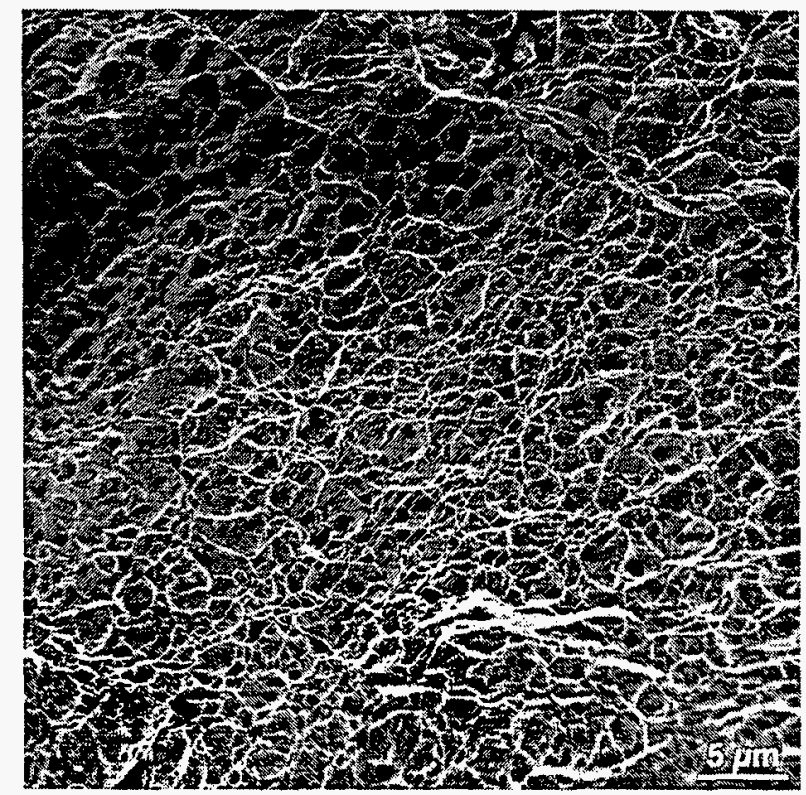

Fig. 10. Ductile fracture surface of asreceived Zircaloy-C.

\subsubsection{Corrosion-Mechanical Tests}

The objective of these tests is to quantitatively determine how corrosion (ICF) impacts the post-test tensile properties of the Zircaloy cladding material. Several iterations in the design of the test specimens and test conditions have been necessary, and data are just becoming available. The design for the tensile test specimen requires considerably more gallium than for the corrosion test design. Dimensional distortion (described previously) at the highest exposure temperature made subsequent tensile testing irrelevant. In view of the problems encountered at $500^{\circ} \mathrm{C}$, and the fact the LWR clad interface temperature is expected to be between 350 and 
$400^{\circ} \mathrm{C}$, further testing of the effects of ICF on mechanical properties is being conducted at lower temperatures. Because the amount of ICF is dependent on time at temperature, dimensional distortion should be nonexistent or very limited even with the required volume of gallium.

One such test $\left(300^{\circ} \mathrm{C}\right.$ for $\left.200 \mathrm{~h}\right)$ has been completed. The fracture surface after subsequent tensile testing at room temperature is shown in Fig. 11. Even though the amount of gallium in the capsule was the same as in previous tests at $500^{\circ} \mathrm{C}$, no distortion occurred at $300^{\circ} \mathrm{C}$. However, in contrast to the ductile fracture surface for as-received material shown in Fig. 10, Zircaloy-C, after contact with gallium at $300^{\circ} \mathrm{C}$ for $200 \mathrm{~h}$, exhibits nonductile features. Gallium was found across the entire wall thickness. This gallium could have flowed across the surface during subsequent mechanical testing at $30^{\circ} \mathrm{C}$ rather than have penetrated the specimen while it was being corrosion tested at $300^{\circ} \mathrm{C}$. However, nonductile features are in keeping with the reduced ductility shown in Fig. 9.

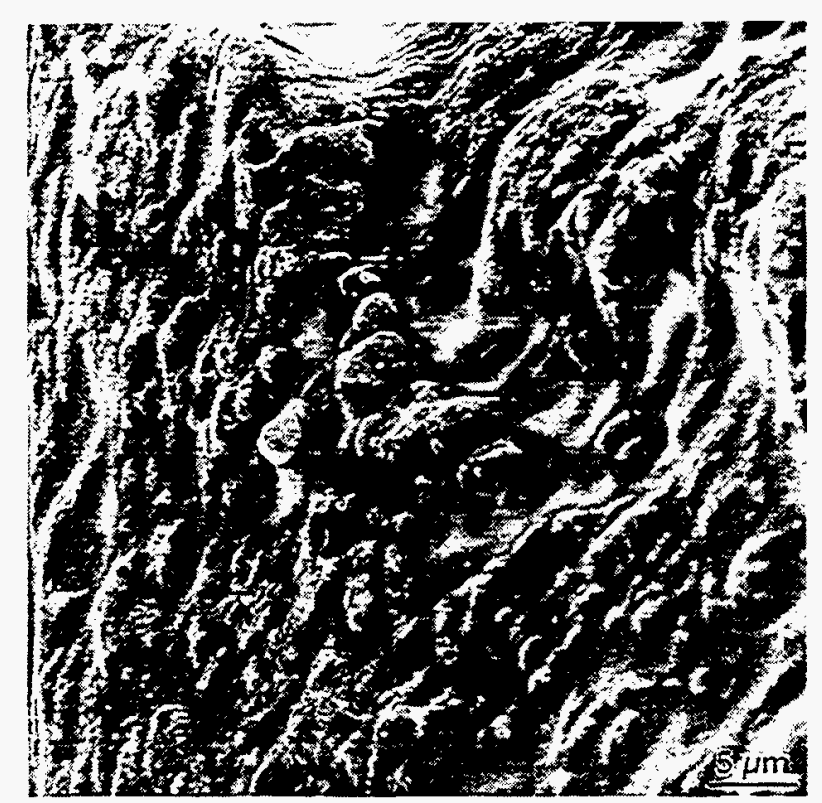

Fig. 11. Nonductile features of fracture surface of Zircaloy-C after $200 \mathrm{~h}$ at $300^{\circ} \mathrm{C}$. 


\subsection{PHASE II CORROSION BY $\mathrm{Ga}_{2} \mathrm{O}_{3}$}

\subsubsection{Corrosion Tests}

The test matrix for corrosion tests of Zircaloy with $\mathrm{Ga}_{2} \mathrm{O}_{3}$ is shown in the appendix. Tests of Zircaloy-B and Zircaloy-C were conducted with $100 \% \mathrm{Ga}_{2} \mathrm{O}_{3}$ powder at 300,500 , and $700^{\circ} \mathrm{C}$ for 6 and 12 weeks respectively. At $300^{\circ} \mathrm{C}$, there was no evidence of interaction as shown in Fig. 12a. At both 500 (Fig. 12b) and $700^{\circ} \mathrm{C}$ (Fig. 12c) an outer layer of $\mathrm{ZrO}_{2}$ formed on the inner diameter of the cladding, and gallium was identified underneath the $\mathrm{ZrO}_{2}$ layer. At $700^{\circ} \mathrm{C}$, the gallium was associated with $\mathrm{ICF}$, but at $500^{\circ} \mathrm{C}$ gallium concentrations were considerably below that in $\mathrm{GaZr}_{2}$, the intermetallic compound that has the lowest gallium concentration. At $500^{\circ} \mathrm{C}$, the thickness of the $\mathrm{ZrO}_{2}$ layer was much less than at $700^{\circ} \mathrm{C}$, and it did not change when the time was increased from 6 to 12 weeks. At $700^{\circ} \mathrm{C}$, the thickness of both the $\mathrm{ZrO}_{2}$ and the ICF layers significantly increased with increasing time of exposure.

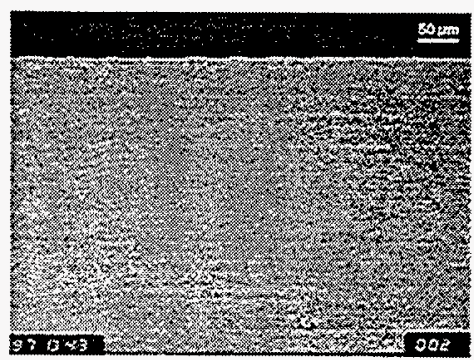

a

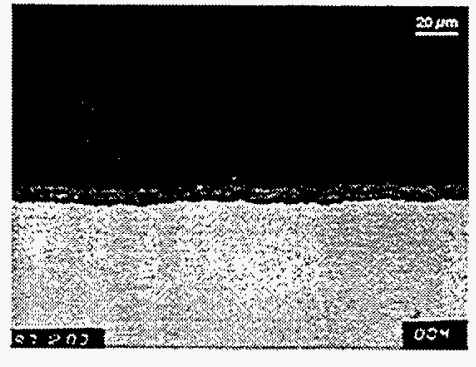

b

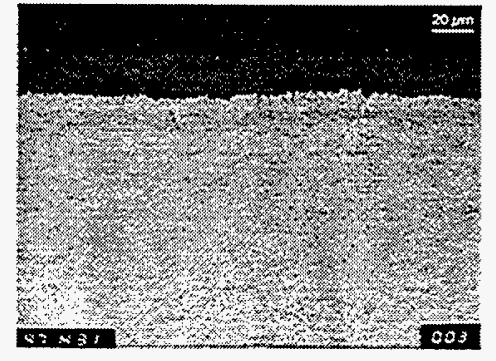

c

Fig. 12. Results of corrosion tests of $\mathrm{Zircaloy}$ with $\mathrm{Ga}_{2} \mathrm{O}_{3}$. a, at $300^{\circ} \mathrm{C}$, shows no evidence of interaction between Zircaloy and $\mathrm{Ga}_{2} \mathrm{O}_{3} ; \mathrm{b}$, at $500^{\circ} \mathrm{C}$, shows $\mathrm{ZrO}_{2}$ at the surface and gallium in solution below the $\mathrm{ZrO}_{2}$ layer; c, at $700^{\circ} \mathrm{C}$, shows $\mathrm{ZrO}_{2}$ at the surface with intermetallic compounds below the $\mathrm{ZrO}_{2}$ layer.

One preliminary test was conducted to determine how a reduced concentration (mass) of $\mathrm{Ga}_{2} \mathrm{O}_{3}$ would affect compatibility with Zircaloy. After 4 weeks exposure at $700^{\circ} \mathrm{C}$, there was very little evidence of interaction when $1778 \mathrm{ppm} \mathrm{Ga}_{2} \mathrm{O}_{3}$ was added to $\mathrm{ZrO}_{2}$ powder. As shown in Fig. 13, interaction was limited to slight cracking and corrosion at the internal diameter surface to a depth of $<13 \mu \mathrm{m}(0.5 \mathrm{mil})$. 

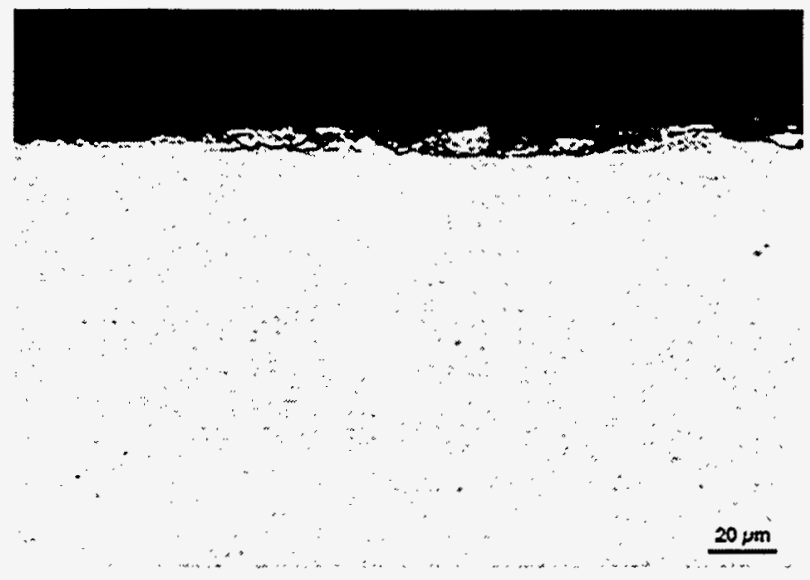

Fig. 13. Little evidence of interaction between $\mathrm{Zircaloy}$ and $1778 \mathrm{ppm} \mathrm{Ga}_{2} \mathrm{O}_{3}$ in $\mathrm{ZrO}_{2}$ after 4 weeks at $700^{\circ} \mathrm{C}$ seen.

\subsubsection{Corrosion-Mechanical Tests}

Difficulties in selecting a suitable diluting medium have resulted in a delay in availability of data. Several approaches have been tried to obtain the expected low level of $\mathrm{Ga}_{2} \mathrm{O}_{3}$ in $\mathrm{MOX}$ fuel required for testing. Both $\mathrm{ZrO}_{2}$ and calcium oxide $(\mathrm{CaO})$ were tried as diluting media. In both cases, there were reactions between the media and the Zircaloy cladding resulting in the growth of zirconium oxide on the surface of the Zircaloy tubing. This oxide growth could render the tests for the effect of $\mathrm{Ga}_{2} \mathrm{O}_{3}$ on the cladding conservative (a thicker oxide layer for the gallium to penetrate). A decision was made to use cerium oxide $\left(\mathrm{CeO}_{2}\right)$ as the diluting medium and blends of $\mathrm{CeO}_{2}$ and $\mathrm{Ga}_{2} \mathrm{O}_{3}$ are being formulated. 


\section{DISCUSSION}

When Zircaloy is exposed to gallium metal, the principal interaction is formation of intermetallic compounds as would be predicted from the gallium-zirconium phase diagram shown in Fig. 14. ${ }^{2}$ The resulting intermetallic phases are quite brittle and, when present in sufficient amounts, reduce the ductility of Zircaloy tubing. However, this type of intermetallic phase formation is mass limited (by the amount of gallium that is available per amount of zirconium) and would not be expected to have any significant effect when the amount of gallium is limited to low levels (parts per million ).

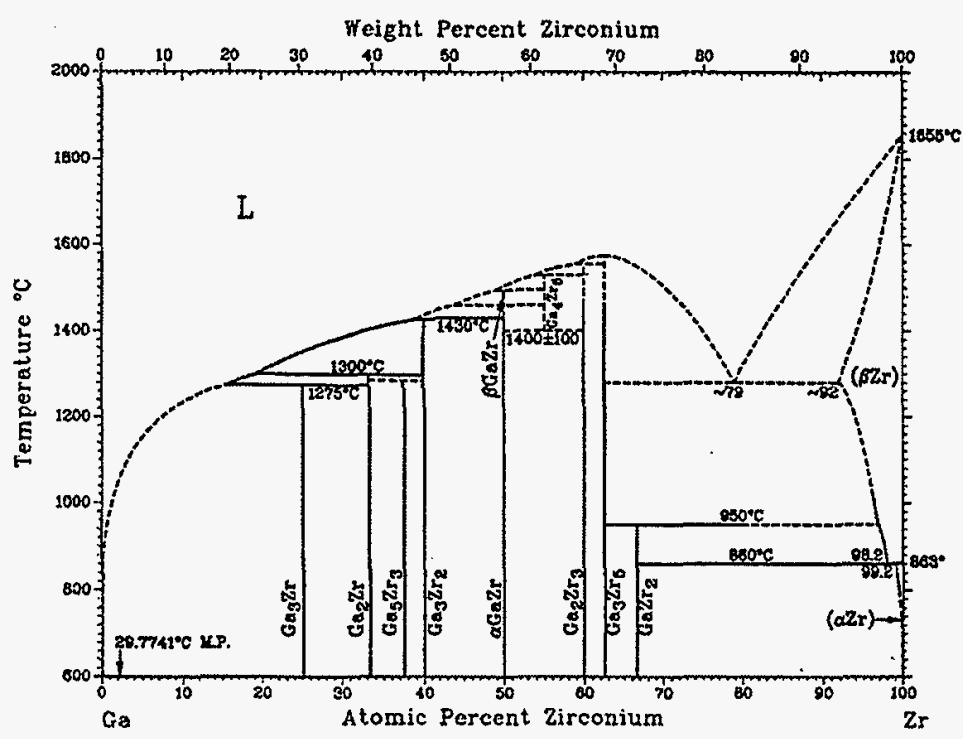

Fig. 14. Ga-Zr phase diagram.

Unreacted gallium available after the initial formation of intermetallic compounds diffuses into the intermetallic compounds thereby causing a significant expansion in the lattice, especially if the concentration of gallium becomes high enough to form the next gallium rich intermetallic compound. This lattice expansion causes large stresses to be generated that result in dimensional distortion of thin-walled material. However, this effect is also mass limited, as demonstrated by the results shown in Fig. 5 , and therefore, clad distortion due to ICF is not to be expected with the very low levels of gallium (10 ppm) present in MOX fuel. In the present tests, when the ratio of mass of gallium to surface area of Zircaloy was $\sim 10^{4}$ higher than expected from gallium in MOX fuel, no distortion was found. 
The potential LME effect of gallium on Zircaloy has not yet been quantitatively established because tensile test ductility measurements were confounded by a mandrel used to reduce the volume of gallium in the Zircaloy test specimen. However, there was no change in the yield and ultimate strengths at room temperature in the presence of gallium. A single test in which Zircaloy was exposed to gallium for $200 \mathrm{~h}$ at $300^{\circ} \mathrm{C}$ did show a measurable decrease in ductility when tensile tested at room temperature. Although there was unreacted gallium present during tensile testing, the reduction in cross section caused by ICF at $300^{\circ} \mathrm{C}$ is the most probable cause for the ductility decrease. However, the cross section of the fracture showed nonductile features, and the possibility that the $300^{\circ} \mathrm{C}$ exposure "preconditioned" the Zircaloy to LME at room temperature cannot be completely discounted.

Because the gallium in MOX fuel is more likely to be present as an oxide rather than as the metal, tests with gallium oxide should produce results more typical of those expected inreactor. With $100 \% \mathrm{Ga}_{2} \mathrm{O}_{3}$ at $300^{\circ} \mathrm{C}$, there was no evidence of Zircaloy- $\mathrm{Ga}_{2} \mathrm{O}_{3}$ interaction. At 500 and $700^{\circ} \mathrm{C}$, reactions as predicted by the second reaction shown on p. 1 were found. At $500^{\circ} \mathrm{C}$, very low levels of gallium were found beneath a $\mathrm{ZrO}_{2}$ layer. This low level of gallium in the Zircaloy was insufficient to produce ICF. However, at $700^{\circ} \mathrm{C}, \mathrm{ICF}$ occurred beneath the oxide layer. Thus, even though Zircaloy cladding is expected to operate in the range from 350 to $400^{\circ} \mathrm{C}$, and the expected level of gallium oxide is quite low, long-term tests are needed to evaluate the possible effects of a gradual increase in the concentration of gallium in Zircaloy, even at low gallium concentrations. Because a decrease in ductility and nonductile fracture features were observed for Zircaloy in contact with gallium at $300^{\circ} \mathrm{C}$ for $200 \mathrm{~h}$, these long-term tests should also include evaluation of mechanical properties. 


\section{CONCLUSIONS}

The initial results have generally been favorable for the use of WG-MOX. This statement is supported by the following conclusions:

- the principal interaction of Zircaloy with gallium is ICF, which will be severely limited by the low mass (in parts per million) of gallium or gallium oxide present;

- while additional gallium migration into the initially formed intermetallic compound results in large stresses that can lead to distortion, this is also unlikely because of the low mass of gallium or gallium oxide present and expected clad temperatures below $400^{\circ} \mathrm{C}$;

- no evidence for grain boundary penetration by gallium has been observed; and

- LME as a possible failure mechanism in the gallium-zirconium system remains largely unresolved primarily because of a lack of significant test results; however, tests are in progress. 


\section{REFERENCES}

1. D. F. Wilson et al., Potential Effects of Gallium on Cladding Materials, ORNL/TM13504, Lockheed Martin Energy Research, Oak Ridge Natl. Lab., 1997.

2. T. B. Massalski, ed., Binary Alloy Phase Diagrams 2, 1880, ASM International, Metals Park, Ohio, 1990.

3. H. S. Rosenbaum, Electrochemical Technology 4, 153 (1966).

4. H. S. Rosenbaum, J. H. Davies, and J. Q. Pon, EURAEC Report, GEAP 5100-5105, 1966.

5. W. T. Grubb, "Cadmium Embrittlement of Zircaloy-2 and Certain Other Metals and Alloys," Embrittlement by Liquid and Solid Metals, 473-484, M . H. Kamdar, ed., The Metallurgical Society of AIME, Warrendale, Penn., 1984.

6. R. P. Gangloff, "Solid Cadmium Embrittlement of Textured Zircaloy-2," Embrittlement by Liquid and Solid Metals, 485-505, M. H. Kamdar, ed., The Metallurgical Society of AIME, Warrendale, Penn., 1984.

7. B. Cox, Environmentally Induced Cracking of Zirconium Alloys: II-Liquid Metal Embrittlement, AECL-3612, Atomic Energy of Canada, Ontario, Canada, 1970.

8. T. Watanabe, S. Shima, and S. Karashima, "Liquid Metal Gallium Induced Intergranular Fracture of Aluminum Bicrystals," Embrittlement by Liquid and Solid Metals, 173-182, M. H. Kamdar, ed., The Metallurgical Society of AIME, Warrendale, Penn., 1984.

9. H. Ichinose and T. Takashima, "Grain Boundary Diffusion and Static Fatigue of Aluminum by Liquid Gallium," Embrittlement by Liquid and Solid Metals, 197-210, M. H. Kamdar, ed., The Metallurgical Society of AIME, Warrendale, Penn., 1984.

10. W. T. Grubb, M. H. Morgan III, "A Survey of Chemical Environments for Activity in the Embrittlement of Zircaloy-2," Proceedings of the Fourth International Conference: Zirconium in the Nuclear Industry, 145-154, ASTM STP 681, American Society for Testing and Materials, Philadelphia, Penn., 1979. 


\section{APPENDIX}

The following tables summarize the status of the work performed. Non-vendor-supplied materials are listed with their trade names. Vendor-supplied materials are listed with generic names.

\section{A.1 Additional compatibility tests of zirconium/Zircaloy with gallium or $\mathbf{G a}_{2} \mathrm{O}_{3}$}

\begin{tabular}{|c|c|c|c|c|}
\hline Material & $\begin{array}{c}\text { Test } \\
\text { environ. }\end{array}$ & $\begin{array}{l}\text { Temp. } \\
\left({ }^{\circ} \mathrm{C}\right)\end{array}$ & $\begin{array}{c}\text { Time } \\
\text { (h) }\end{array}$ & Comments \\
\hline $\mathrm{Zr}$ & $\mathrm{Ga}$ & 400 & 100 & Intermetallic compound formation (ICF) \\
\hline $\mathrm{Zr}$ & $\mathrm{Ga}$ & 600 & 134 & ICF \\
\hline Zircaloy-2 & $\mathrm{Ga}$ & 400 & 100 & ICF \\
\hline Zircaloy-2 & $\mathrm{Ga}$ & 600 & 100 & ICF \\
\hline Zircaloy-2 & $\mathrm{Ga}_{2} \mathrm{O}_{3}$ & 400 & 200 & Thin $\mathrm{ZrO}_{2}$ layer visible at $1000 \mathrm{X}$ \\
\hline Zircaloy-2 & $\mathrm{Ga}_{2} \mathrm{O}_{3}$ & 600 & 200 & Slightly thicker $\mathrm{ZrO}_{2}$ layer visible at $1000 \mathrm{X}$ \\
\hline Zircaloy-2 & $\mathrm{Ga}_{2} \mathrm{O}_{3}$ & 500 & 672 & $\mathrm{ZrO}_{2}$ layer plus $\mathrm{Ga}$ within alloy \\
\hline Zircaloy-2 & $\mathrm{Ga}_{2} \mathrm{O}_{3}$ & 500 & 2016 & $\begin{array}{l}\mathrm{ZrO}_{2} \text { layer plus } \mathrm{Ga} \text { within alloy; no change } \\
\text { in thickness (compared to } 4 \text { weeks) }\end{array}$ \\
\hline Zircaloy-4 & $\mathrm{Ga}_{2} \mathrm{O}_{3}$ & 700 & 672 & $\begin{array}{l}\text { Much thicker } \mathrm{ZrO}_{2} \text { layer (compared to } \\
500^{\circ} \mathrm{C} \text { ) plus ICF below oxide; cracks in } \\
\mathrm{ZrO}_{2}\end{array}$ \\
\hline Zircaloy-4 & $\mathrm{Ga}_{2} \mathrm{O}_{3}$ & 700 & 2016 & $\begin{array}{l}4 \text { mil } \mathrm{ZrO}_{2} \text { layer plus } 3 \text { mils of ICF below } \\
\text { oxide }\end{array}$ \\
\hline Zircaloy-B (vendor) & $\mathrm{Ga}$ & 500 & 200 & $\begin{array}{l}\text { Electron beam welding (EBW) (vacuum); } \\
\text { ICF; very slight distortion }\end{array}$ \\
\hline Zircaloy-C (vendor) & $\mathrm{Ga}$ & 500 & 200 & EBW (vacuum); ICF; distortion \\
\hline Zircaloy-B (vendor) & $\mathrm{Ga}$ & 500 & 200 & $\begin{array}{l}\text { Thin end cap ( } 0.50 \text { in.); ICF; very slight } \\
\text { distortion }\end{array}$ \\
\hline Zircaloy-B (vendor) & $\mathrm{Ga}$ & 500 & 200 & $\begin{array}{l}\text { Thick end cap ( } 0.2 \text { in.) with circumferential } \\
\text { laser beam welding (LBW) of end cap to } \\
\text { seal crevice; ICF; distortion }\end{array}$ \\
\hline Zircaloy-C (vendor) & $\mathrm{Ga}$ & 500 & 200 & Thin end cap; ICF; distortion \\
\hline Zircaloy-C (vendor) & $\mathrm{Ga}$ & 500 & 200 & Thick end cap with LBW; ICF; distortion \\
\hline Zircaloy-C (vendor) & $\mathrm{Ga}$ & 500 & 200 & $\sim 650 \mathrm{ppm} \mathrm{Ga}$ in $\mathrm{ZrO}_{2}$ powder \\
\hline Zircaloy-C (vendor) & $\mathrm{Ga}$ & 500 & 200 & $\begin{array}{l}\sim 650 \mathrm{ppm} \mathrm{Ga} \text { at bottom of capsule covered } \\
\text { with } \mathrm{ZrO}_{2} \text { powder }\end{array}$ \\
\hline Zircaloy-4 & $\mathrm{Ga}_{2} \mathrm{O}_{3}$ & 700 & 672 & $\begin{array}{l}\sim 1800 \mathrm{ppm} \mathrm{Ga}_{2} \mathrm{O}_{3} \text { blended with } \mathrm{ZrO}_{2} \\
\text { interaction to }<0.5 \mathrm{mil}\end{array}$ \\
\hline
\end{tabular}




\section{A-2}

A.2 Status of corrosion tests of Zircaloy with gallium metal

\begin{tabular}{|c|c|c|c|c|c|c|}
\hline \multirow[b]{2}{*}{ Material } & \multirow{2}{*}{$\begin{array}{c}\text { Time } \\
\text { (h) }\end{array}$} & \multicolumn{4}{|c|}{ Temperature $\left({ }^{\circ} \mathrm{C}\right)$} & \multirow[b]{2}{*}{ Comment } \\
\hline & & 30 & 100 & 500 & $500^{*}$ & \\
\hline \multirow{2}{*}{$\begin{array}{l}\text { Zircaloy-A } \\
\text { (vendor) }\end{array}$} & 200 & & & $\mathrm{x}$ & $x$ & \\
\hline & 700 & $\mathbf{x}$ & $\mathrm{x}$ & $\mathrm{x}$ & $\mathrm{x}$ & \\
\hline \multirow{2}{*}{$\begin{array}{l}\text { Zircaloy-B } \\
\text { (vendor) }\end{array}$} & 200 & & & $\checkmark$ & $\checkmark$ & $\begin{array}{l}\text { Intermetallic compound formation (ICF); } \\
\text { dimensional distortion }\end{array}$ \\
\hline & 700 & $\checkmark$ & $\checkmark$ & $\checkmark$ & $\checkmark$ & $\begin{array}{l}\text { No attack at } 30 \text { or } 100^{\circ} \mathrm{C} ; \mathrm{ICF} \text { at } 500^{\circ} \mathrm{C} \\
\text { but no increase over } 200 \mathrm{~h} \text {; dimensional } \\
\text { distortion }\end{array}$ \\
\hline & 200 & & & $\checkmark$ & $\checkmark$ & ICF; dimensional distortion \\
\hline $\begin{array}{l}\text { Zircaloy-C } \\
\text { (vendor) }\end{array}$ & 700 & $\checkmark$ & $\checkmark$ & $\checkmark$ & $\checkmark$ & $\begin{array}{l}\text { No attack at } 30 \text { or } 100^{\circ} \mathrm{C} \text {; ICF at } 500^{\circ} \mathrm{C} \\
\text { but no increase over } 200 \mathrm{~h} \text {; dimensional } \\
\text { distortion at } 500^{\circ} \mathrm{C}\end{array}$ \\
\hline
\end{tabular}

- With cadmium

$\mathrm{x}$ - Scheduled test

$\checkmark$ - Completed test

\section{A.3 Status of corrosion tests of Zircaloy with $\mathrm{Ga}_{2} \mathrm{O}_{3}$}

\begin{tabular}{|c|c|c|c|c|c|c|}
\hline \multirow[b]{2}{*}{ Materials } & \multirow{2}{*}{$\begin{array}{l}\mathrm{Ga}_{2} \mathrm{O}_{3} \\
(\mathrm{wt} \%)\end{array}$} & \multirow{2}{*}{$\begin{array}{c}\begin{array}{c}\text { Time } \\
\text { (weeks) }\end{array} \\
\end{array}$} & \multicolumn{3}{|c|}{ Temperature $\left({ }^{\circ} \mathrm{C}\right)$} & \multirow[b]{2}{*}{ Comment } \\
\hline & & & 300 & 500 & 700 & \\
\hline \multirow{5}{*}{$\begin{array}{l}\text { Zircaloy-A } \\
\text { (vendor) }\end{array}$} & 100 & 6 & $\mathrm{x}$ & $\mathrm{x}$ & $\mathrm{x}$ & \\
\hline & 100 & 12 & $\mathrm{x}$ & $\mathrm{x}$ & $x$ & \\
\hline & 1 & 6 & $\mathrm{x}$ & $\mathrm{x}$ & $x$ & \\
\hline & 0.2 & 6 & $\mathrm{x}$ & $x$ & $\mathrm{x}$ & \\
\hline & 0.1 & 6 & $x$ & $x$ & $x$ & \\
\hline \multirow{5}{*}{$\begin{array}{l}\text { Zircaloy-B } \\
\text { (vendor) }\end{array}$} & 100 & 6 & $\checkmark$ & $\checkmark$ & $\checkmark$ & $\begin{array}{l}\text { No interaction at } 300^{\circ} \mathrm{C} ; \mathrm{ZrO}_{2} \text { at } 500 \\
\text { and } 700^{\circ} \mathrm{C} \text {; intermetallic compound } \\
\text { formation (ICF) at } 700^{\circ} \mathrm{C}\end{array}$ \\
\hline & 100 & 12 & $\checkmark$ & $\checkmark$ & $\checkmark$ & $\begin{array}{l}\text { Same as for } 6 \text { weeks except greater } \\
\text { depth of interaction at } 700^{\circ} \mathrm{C}\end{array}$ \\
\hline & 1 & 6 & $\mathrm{x}$ & $x$ & $\mathrm{x}$ & \\
\hline & 0.2 & 6 & $x$ & $x$ & $\mathrm{x}$ & \\
\hline & 0.1 & 6 & $x$ & $\mathrm{x}$ & $x$ & \\
\hline \multirow{5}{*}{$\begin{array}{l}\text { Zircaloy-C } \\
\text { (vendor) }\end{array}$} & 100 & 6 & $\checkmark$ & $\checkmark$ & $\checkmark$ & $\begin{array}{l}\text { No interaction at } 300^{\circ} \mathrm{C} ; \mathrm{ZrO}_{2} \text { at } 500 \\
\text { and } 700^{\circ} \mathrm{C} ; \mathrm{ICF} \text { at } 700^{\circ} \mathrm{C}\end{array}$ \\
\hline & 100 & 12 & $\checkmark$ & $\checkmark$ & $\checkmark$ & $\begin{array}{l}\text { Same as for } 6 \text { weeks except greater } \\
\text { depth of interaction at } 700^{\circ} \mathrm{C}\end{array}$ \\
\hline & 1 & 6 & $x$ & $\mathrm{x}$ & $\mathrm{x}$ & \\
\hline & 0.2 & 6 & $\mathrm{x}$ & $x$ & $\mathbf{x}$ & \\
\hline & 0.1 & 6 & $\mathrm{x}$ & $\mathrm{x}$ & $x$ & \\
\hline
\end{tabular}

$\mathrm{x}$ - Scheduled

$\checkmark$-Completed 


\section{A-3}

\section{A.4 Status of mechanical tests of Zircaloy with gallium metal}

\begin{tabular}{|c|c|c|c|c|c|c|}
\hline \multirow[b]{2}{*}{ Material } & \multirow[b]{2}{*}{ Type } & \multicolumn{4}{|c|}{ Temperature $\left({ }^{\circ} \mathrm{C}\right)$} & \multirow[b]{2}{*}{ Comment } \\
\hline & & 30 & 100 & 300 & $300^{*}$ & \\
\hline \multirow{2}{*}{$\begin{array}{l}\text { Zircaloy-A } \\
\text { (vendor) }\end{array}$} & LME & $\mathrm{x}$ & $\mathrm{x}$ & & & \\
\hline & $\mathrm{CM}$ & & & $\mathbf{x}$ & $x$ & \\
\hline \multirow{2}{*}{$\begin{array}{l}\text { Zircaloy-B } \\
\text { (vendor) }\end{array}$} & LME & $\mathrm{x}$ & $\mathrm{x}$ & & & \\
\hline & $\mathrm{CM}$ & & & $\mathrm{x}$ & $\mathrm{x}$ & \\
\hline \multirow{2}{*}{$\begin{array}{l}\text { Zircaloy-C } \\
\text { (vendor) }\end{array}$} & LME & $\mathbf{x}$ & $\mathrm{x}$ & & & \\
\hline & $\mathrm{CM}$ & & & $\boldsymbol{V}$ & $\mathrm{x}$ & $\begin{array}{l}\text { Fracture surface exhibited nonductile } \\
\text { features }\end{array}$ \\
\hline
\end{tabular}

- With cadmium

$\mathrm{x}$ - Scheduled test

$\checkmark$-Completed test

LME - Constant extension rate tensile (CERT) test at temperature (triplicate tests)

$\mathrm{CM}-\mathrm{CERT}$ test at room temperature after $200 \mathrm{~h}$ at temperature (triplicate tests)

\section{A.5 Status of corrosion-mechanical" tests of Zircaloy with $\mathrm{Ga}_{2} \mathrm{O}_{3}$}

\begin{tabular}{|c|c|c|c|c|c|}
\hline \multirow[b]{2}{*}{ Materials } & \multirow{2}{*}{$\begin{array}{l}\mathrm{Ga}_{2} \mathrm{O}_{3} \\
(\mathrm{wt} \%)\end{array}$} & \multicolumn{3}{|c|}{ Temperature $\left({ }^{\circ} \mathrm{C}\right)$} & \multirow[b]{2}{*}{ Comment } \\
\hline & & 300 & 500 & 700 & \\
\hline \multirow{4}{*}{$\begin{array}{l}\text { Zircaloy-A } \\
\text { (vendor) }\end{array}$} & 100 & $x$ & $x$ & $\bar{x}$ & \\
\hline & 1 & $\mathrm{x}$ & $x$ & $\mathrm{x}$ & \\
\hline & 0.2 & $\mathrm{x}$ & $x$ & $x$ & \\
\hline & 0.1 & $\mathrm{x}$ & $\mathrm{x}$ & $\mathrm{x}$ & \\
\hline \multirow{4}{*}{$\begin{array}{l}\text { Zircaloy-B } \\
\text { (vendor) }\end{array}$} & 100 & $x$ & $\mathrm{x}$ & $x$ & \\
\hline & 1 & $\mathrm{x}$ & $\mathrm{x}$ & $\mathrm{x}$ & \\
\hline & 0.2 & $\mathrm{x}$ & $\mathrm{x}$ & $\mathrm{x}$ & \\
\hline & 0.1 & $\mathrm{x}$ & $\mathrm{x}$ & $x$ & \\
\hline \multirow{4}{*}{$\begin{array}{l}\text { Zircaloy-C } \\
\text { (vendor) }\end{array}$} & 100 & $\mathrm{x}$ & $\mathrm{x}$ & $x$ & \\
\hline & 1 & $\mathrm{x}$ & $x$ & $\mathrm{x}$ & \\
\hline & 0.2 & $\mathrm{x}$ & $\mathrm{x}$ & $\mathrm{x}$ & \\
\hline & 0.1 & $x$ & $\mathrm{x}$ & $x$ & \\
\hline
\end{tabular}

$\mathrm{x}$ - Scheduled

- Constant extension rate tensile test at room temperature after 6 weeks at temperature (triplicate tests) 
ORNL/TM-13505

Dist. Category UC-523

\section{INTERNAL DISTRIBUTION}

1. E. C. Beahm

2. T. M. Besmann

3. B. B. Bevard

4. C. A. Baldwin

5. R. A. Bradley

6. S. L. Byerly

7. E. D. Collins

8. B. S. Cowell

9. D. F. Craig

10. J. H. DeVan

11-13. J. R. DiStefano

14. E. E. Duncan

15. E. C. Fox

16. U. Gat

17. R. G. Gilliland

18. S. R. Greene

19. H. W. Hayden

20. S. A. Hodge

21. J. A. Horak

22. L. L. Horton

23. J. R. Keiser

24-26. J. F. King

27-29. E. T. Manneschmidt
30. S. R. Martin, Jr., DÓE/ORO

31. G. T. Mays

32. G. E. Michaels

33. R. N. Morris

34. N. H. Packan

35. S. J. Pawel

36. R. T. Primm, III

37. D. G. O'Connor

38. L. J. Ott

39. R. R. Rahn

40. P. L. Rittenhouse

41. J. D. Sease

42. D. J. Spellman

43. C. C. Southmayd

44-46. J. P. Strizak

47. K. R. Thoms

48. D. L. Williams, Jr.

49-58. D. F. Wilson

59. B. A. Worley

60-61. Central Research Library

62-63. ORNL Laboratory Records-RC

64. FMDP Library

\section{EXTERNAL DISTRIBUTION}

65. M. L. Adams, Amarillo National Resource Center for Plutonium, Department of Nuclear Engineering, Texas A\&M University, College Station, TX 77843-3133.

66. D. Alberstein, Los Alamos National Laboratory, P. O. Box 1663, Los Alamos, NM 87545.

67. J. F. Baker, U.S. Department of Energy, MD-1, Forrestal Building, 1000 Independence Avenue SW, Washington, DC 20585.

68. T. Barr, U.S. Department of Energy, EPG, Argonne National Laboratory, 9800 South Cass Avenue, Argonne, IL 60439.

69. F. R. Best, Amarillo National Resource Center for Plutonium, Associate Professor, Department of Nuclear Engineering, Texas A\&M University, College Station, TX 77843-3133. 
70. J. J. Buksa, Los Alamos National Laboratory, P.O. Box 1663, MS-F628, Los Alamos, NM 87545.

71. D. P. Butt, Los Alamos National Laboratory, P. O. Box 1663, MS-G755, Los Alamos, NM 87545.

72. H. R. Canter, U.S. Department of Energy, MD-1, Forrestal Building, 1000 Independence Avenue SW, Washington, DC 20585.

73. A. I. Cygelman, U.S. Department of Energy, MD-3, Forrestal Building, 1000 Independence Avenue SW, Washington, DC 20585.

74. T. H. Gould, Jr., Lawrence Livermore National Laboratory, P. O. Box 808, MS-L186, Livermore, CA 94551.

75. R. J. Hanrahan Jr., Los Alamos National Laboratory, P. O. Box 1663, MS-G770, Los Alamos, NM 87545.

76. R. R. Hart, Amarillo National Resource Center for Plutonium, Professor, Department of Nuclear Engineering, Texas A\&M University, College Station, TX 77843-3133.

77. H. C. Irwin, Sandia National Laboratories, P. O. Box 969, MS-9015, Livermore, CA 94551.

78. S. O'Kelly, Amarillo National Resource Center for Plutonium, Assistant Director, Nuclear Science Center, Texas A\&M University, College Station, TX 77843-3575.

79. D. J. Nulton, U.S. Department of Energy, MD-4, Forrestal Building, Room 6G-050, 1000 Independence Avenue SW, Washington, DC 20585.

80-81. Office of Scientific and Technical Information, P. O. Box 62, Oak Ridge, TN 37831.

82-83. C. J. Paone, General Electric Company, P. O. Box 780, M/C A16, 3901 Castle Hayne Road, Wilmington, NC 28402.

84. D. Peko, U.S. Department of Energy, MD-3, Forrestal Building, Room 6G-050, 1000 Independence Avenue SW, Washington, DC 20585.

85-89. P. T. Rhoads, U.S. Department of Energy, MD-3, Forrestal Building, Room 6G-050, 1000 Independence Avenue SW, Washington, DC 20585.

90-91. S. Ritterbusch, ABB Combustion Engineering Nuclear Systems, 2000 Day Hill Road, Windsor, CT 06095-0500.

92. J. M. Ryskamp, Idaho National Engineering and Environmental Laboratory, P. O. Box 1625, Idaho Falls, ID 83415-3885.

93. R. H. Steele, MPR Associates, Inc., 320 King Street, Alexandria, VA 22314-3238. 
94. G. B. Stevenson, U.S. Department of Energy, MD-4, Forrestal Building, Room 6G-050, 1000 Independence Avenue SW, Washington, DC 20585.

95-96. M. Travis, Westinghouse Electric Corporation, P. O. Box 355, Pittsburgh, PA 15230.

97. J. H. Thompson, U.S. Department of Energy, MD-4, Forrestal Building, Room 6G-050, 1000 Independence Avenue SW, Washington, DC 20585.

98. S. S. Voss, Los Alamos National Laboratory, P.O. Box 1663, MS-F628, Los Alamos, NM 87545. 


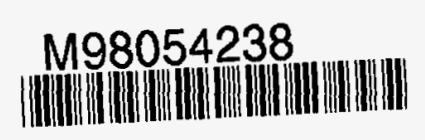

Report Number (14)ORNL/Tm.. 13505

Publ. Date (11)

Sponsor Code (18) DDE/MD, XF
UC Category (19) UC-900, DOE/ER

DTIC QUALTTY INSTHULLD 5

\section{1}

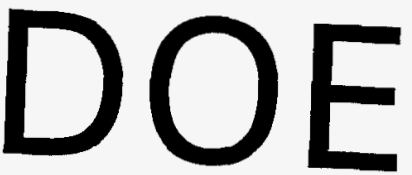

